\title{
PEMFIGUS VULGARIS ORAL TERKAIT INFEKSI VIRUS HERPES SIMPLEKS
} (Laporan Kasus)

\section{Surya Nelis ${ }^{\varpi^{*}}$}

\begin{abstract}
ABSTRAK
Pemfigus vulgaris (PV) merupakan penyakit autoimun yang menyerang kulit dan membran mukosa yang ditandai dengan pembentukan blister intra epitel, yang terjadi karena adanya interaksi antara faktor predisposisi genetik dan lingkungan. Infeksi yang disebabkan oleh anggota keluarga virus herpes telah diajukan sebagai suatu barangkali menjadi faktor pemicu terjadinya PV. Laporan kasus ini bertujuan untuk menggambarkan suatu kasusPV yang terjadi pada seorang pasien setelah menunjukkan infeksi virus herpes, yang refractoryterhadap terapi kortikosteroid.

Seorang pasien perempuan berusia 49 tahun dengan ulserasi dan erosi multipel yang luas dan sangat sakit.di mulut. Lesi awalnya muncul di mukosa bukal yang selanjutnya meluas melibatkan seluruh mukosa mulut. Pemeriksaan histopatologis menujukkan kesan PV. Lesi berkembang bersamaan dengan titer antibodi yang tinggi terhadap virus herpes simpleks. Pasien dirawat dengan kortikosteroid oral dan topikal, tetapi menunjukkan remisi yang tidak menyeluruh. Titer anti-HSV mengikuti aktivitas PV, menurun dengan remisi penyakit. Dua bulan setelah remisi, pasien mengalami eksaserbasi lesi, mengikuti kembalinya titer IgG antiHSV yang tinggi.

Perawatan dengan asiklovir menunjukkan keberhasilan dan semua lesi sembuh menyeluruh. Kasus ini mengindikasikan bahwalesi PV yang refractory terhadap terapi kortikosteroid, sebaiknya dipertimbangkan adanya kemungkinan infeksi virus herpes.
\end{abstract}

Kata kunci : Pemfigus vulgaris oral, infeksi herpes simpleks, autoimun, kortikosteroid

\begin{abstract}
Pemphigus Vulgaris (PV) is an autoimmune mucocutaneous disease characterized by intraepithelial blister formation, which develops due to the interaction between predisposing genetic and environmental factors. Infections caused by members of the Herpesviridae family have been suggested as a possible triggering factor for PV. The purpose of this case report was to describe the case of a patient who has developed PV after showing herpetic infection, which refractory to corticosteroid therapy.

A 49-year old-woman suffered from extensive multiple painful erosions/ulcers of the mouth. The lesions started on the buccal mucosa which subsequently involved the entired mouth. Histopathologic examination was suggestive of PV. The lesions developed concurrently with high titers of anti-HSV antibodies. These patient was treated with oral and topical corticosteroid, but showed incomplete remission. The titers of anti-HSV have followed the PV activity, reducing with the remission of the disease. Two months later, patient developed exacerbation of the lesions, following the return of high titers of anti-HSV IgG.

The treatment with acyclovir has succeeded and all lesions have been completely healed. This case indicated that the lesions of $P V$ which are refractory to corticosteroid therapy, should be considered to herpetic infection.
\end{abstract}

Keywords : Oral pemphigus vulgaris, herpes simplex infection, autoimmune, corticosteroids

\footnotetext{
${ }^{*}$ Lecturer of Department of Oral Medicine, Faculty of Dentistry, Andalas University

: nelis9surya@gmail.com
} 


\section{PENDAHULUAN}

Pemfigus Vulgaris (PV) merupakan penyakit autoimun yang menyerang membran mukosa dan kulit, ditandai dengan pembentukan blister intraepitel. Etiologi dan patogenesis yang pasti masih belum diketahui dengan jelas, namun berkaitan erat dengan faktor endogen (genetik) dan adanya interaksi dengan faktor eksogen. Salah satu faktor eksogen yang berperan dalam terjadinya PV adalah virus. Infeksi virus seperti herpes simplex virus (HSV), EpsteinBarr virus (EBV), cytomegalovirus (CMV) dan herpes virus 8 (HHV 8), berperan penting dalam memulai dan mencetuskan PV, serta mempertahankan dan memperburuk kondisi penyakit. Agen infeksi dapat merangsang respon imun pada individu yang rentan secara genetik, yang berkontribusi pada produksi limfosit B yang autoreaktif dan antibodi autoimun.

Salah satu aspek penting dalam manajemen pasien adalah diagnosis pada tahap awal. Mukosa mulut merupakan tempat pertama yang terlibat dalam mayoritas kasus. Lesi oral dapat berkembang hingga 1 tahun sebelum lesi kulit muncul. jika PV oral dapat dikenal pada tahap awal, terapi dapat segera dimulai untuk mencegah perkembangan penyakit agar tidak melibatkan kulit atau mengurangi keparahannya. Kortikosteroid sistemik masih merupakan pilihan utama terapi. Beberapa literatur telah menguraikan sejumlah kasus HSV sebagai faktor pencetus atau memperburuk kondisi PV yang telah ada. Pada kasus yang demikian, diamati bahwa remisi menyeluruh dari lesi hanya terjadi setelah pemberian obat antivirus.

Laporan kasus ini bertujuan untuk menggambarkan kasus PV oral yang terjadi pada seorang pasien perempuan bersamaan dengan level titer antibodi anti-HSV yang tinggi. Remisi yang cepat dan menyeluruh terjadi setelah pemberian asiklovir dosis tinggi.

\section{PENALAKSANAAN KASUS}

Seorang pasien perempuan berusia 49 tahun dikonsulkan dari poliklinik THT ke poliklinik penyakit mulut dengan riwayat sariawan sejak 1 bulan yang lalu dan tidak kunjung sembuh. Dari anamnesis diperoleh informasi bahwa awalnya luka berupa lentingan muncul pada mukosa bukal, lalu pecah. Lama kelamaan luka bertambah lebar dan banyak. Luka muncul tidak didahului demam, tidak ada luka yang sama di bagian tubuh lain. Penyakit ini baru pertama kali dialami pasien. Riwayat pengobatan yang sudah didapatkan yaitu asiklovir $5 \times 200 \mathrm{mg}$ selama 7 hari, antibiotika, salep triamsinolon asetonid $0,1 \%$, anti jamur topikal, obat kumur khlorheksidin glukonat dan multivitamin. Tidak ada riwayat penyakit sistemik maupun penggunaan obat-obatan. Pada pemeriksaan klinis tampak daerah erosif dan sloughing pada mukosa labial bawah, mukosa bukal kanan kiri, dorsolateral lidah kanan, ventral lidah, palatum molle, dan mukosa labial bawah. Dasar mulut tampak eritema, dan deskuamasi pada gingiva anterior rahang atas dan bawah. Higiene oral buruk dengan kalkulus sub dan supra gingiva.

Berdasarkan riwayat dan gambaran klinis penyakit, diagnosis kerja ditegakkan pada Pemfigus Vulgaris (PV) Oral dengan diagnosis banding Herpes Associated Erythema Multiform (HAEM) dan Mucous Membrane Pemphigoid (MMP). Pasien diberikan resep obat kumur yang mengandung antibotika $250 \mathrm{mg} 3 \times$ /hari, dipenhydramin $\mathrm{HCl}$ gargle, serta multivitamin. Pasien diinstruksikan untuk mengganti pasta gigi dengan yang nondetergen dan membersihkan karang gigi. Pasien dirujuk untuk pemeriksaan Darah Perifer Lengkap (DPL) dan pemeriksaan serologi untuk anti HSV (Herpes Simplex Virus) 1 dan 2 IgG dan IgM.

Kontrol 1 minggu kemudian menunjukkan kondisi mulut pasien semakin parah. Pemeriksaan klinis (gambar 1) tampak krusta merah kehitaman pada bibir bawah. 
Daerah erosif, sloughing dan ulserasi makin meluas di mukosa bukal, labial, lidah dan dasar mulut, deskuamatif gingivitis tampak menyeluruh. Hasil pemeriksaan DPL menunjukkan kadar hemoglobin $(\mathrm{Hb})$, hematokrit (Ht), eritrosit, eosinofil dan laju endap darah (LED) sedikit lebih tinggi dari nilai normal. Pemeriksaan serologi $\mathrm{IgG}$ untuk HSV-1 menunjukkan hasil yang reaktif, hampir 12 kali lebih tinggi dari batas normal (10,33). Pasien diberi resep methyl prednisolone (MP) kumur telan dengan dosis $3 \times 8 \mathrm{mg}$ sehari, vaselin album untuk dioles pada bibir, serta multivitamin. Pasien dikonsulkan ke bagian penyakit dalam untuk evaluasi kemungkinan adanya penyakit sistemik berkaitan dengan beberapa hasil DPL yang lebih tinggi dari nilai normal.

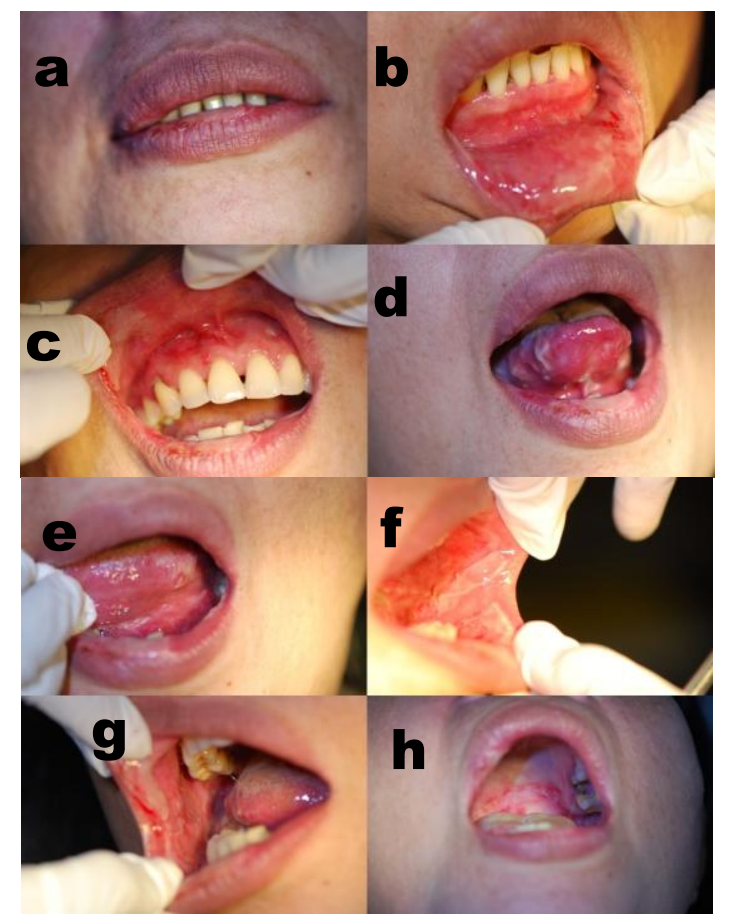

Gambar 1. (a) krusta merah kehitaman pada bibir bawah. Erosi dan sloughing yang meluas pada (b\&c) mukosa labial atas \& bawah serta gingival, (d\&e) ventral \& lateral lidah dan dasar mulut, (f\&g) mukosa bukal kiri-kanan, dan (h) palatum molle

Pasien kontrol 5 hari kemudian, terlihat gejala dan tanda klinis makin memberat. Tampak ulserasi yang cukup dalam pada mukosa bukal kanan regio 48 dan daerah komisura mukosa bukal kiri disertai perdarahan spontan. Pasien diberikan resep MP per oral 3x16mg per hari, prednison $3 \times 10 \mathrm{mg}$ kumur buang, ranitidin tablet dan betadine gargle. Kontrol selanjutnya, pasien tetap diberikan tablet MP per oral dan prednison kumur dengan dosis tape off. Tiga minggu kemudian tampak daerah erosif, sloughing dan ulserasi makin berkurang, namun pasien mengeluhkan pipi terasa membulat, lidah terasa kasar, panas dan perih. Tampak plak putih pada mukosa bukal kanan dan lateral lidah kanan-kiri. Plak dapat diseka/diangkat dengan bantuan kain kassa, meninggalkan daerah eritema. Hasil pemeriksaan swab lidah menunjukan sel-sel jamur dan pseudohifa positif. Pasien diberi resep antijamur topikal berupa suspensi 4x1ml. Dosis MP diturunkan menjadi 2x8mg dan prednison kumur dihentikan dan diganti dengan salep triamsinolon asetonid $0,1 \%$. Pasien juga diberi obat asam folat dan kalsium untuk 1 bulan.

Satu bulan kemudian, tampak ulserasi dalam proses penyembuhan (mengecil dan menipis), plak putih sudah menghilang. Pasien diinstruksikan untuk meneruskan pemakaian triamsinolon asetonid $0,1 \%$, sedangkan MP dan obat antijamur dihentikan. Hasil pemeriksaan serologi menunjukan anti HSV-1 IgG 5,3.

Tiga bulan kemudian, pasien kembali dikonsulkan dari poli kulit. Menurut pasien, sejak 3 minggu yang lalu luka di mulut kembali bertambah banyak, dan luka yang sama mulai muncul di kulit (7 bulan setelah lesi di mulut). Pasien sudah mendapat obat MP $40 \mathrm{mg} / \mathrm{hari}$ dari poli kulit, saat ini direncanakan tape off. Pemeriksaan intra oral tampak ulser dangkal memanjang pada mukosa bukal regio 36-38 dan 46-48, mukobukal fold regio 38, 44-45, ventral lidah, dan gingiva regio 46; sloughing dan eritema di mukosa bukal dan palatum molle, deskuamatif gingivitis regio 44-45. Pemeriksaan serologi menunjukan anti HSV1 IgG reaktif $(10,41)$. Pasien diberikan resep prednison kumur 3x5mg, khlorheksidin glukonat kumur, dan asiklovir 4x400mg per 
hari. Pasien dirujuk untuk pemeriksaan histologi.

Pemeriksaan klinis 2 minggu kemudian menunjukkan kondisi rongga mulut tidak ada perbaikan, daerah eritema dan sloughing makin meluas, deskuamatif gingivitis semakin parah pada rahang bawah (gambar 2). Tampak ulser baru di apeks lidah dan palatum molle. Pemberian obat asiklovir ditingkatkan menjadi 4x800 mg per hari. Hasil biopsi (sediaan berasal dari mukosa bukal) menunjukan epitel setempat tampak terpisah dan akantolitik; ditemukan sel Tzank; lapisan basal tetap melekat ke membran basal; lamina propria bersebukan keras sel radang kronik, dengan banyak pembuluh darah yang kongestif.

Sepuluh hari kemudian terlihat kondisi rongga mulut telah mengalami penyembuhan, hanya terlihat sedikit daerah eritema di regio 38 (gambar 3). Hasil pemeriksaan serologi menunjukkan anti HSV-1 IgG masih tetap reaktif, namun menunjukkan penurunan menjadi 6,23.

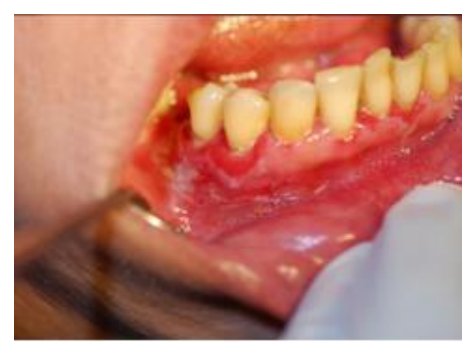

Gambar 2. deskuamatif gingivitis yang makin parah pada RB.

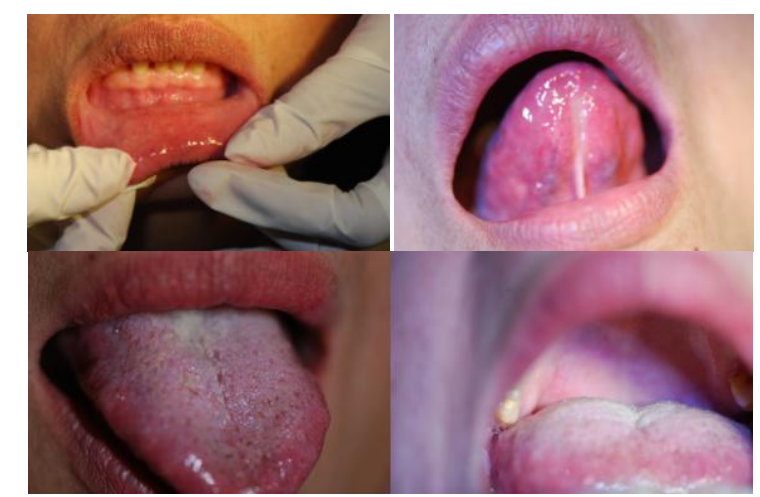

Gambar 3. Tampak lesi telah mengalami penyembuhan setelah pemberian asiklovir dosis tinggi

\section{PEMBAHASAN}

Pemfigus Vulgaris (PV) merupakan penyakit kronis yang menyerang membran mukosa dan kulit, biasanya bermanifestasi pertamakali pada rongga mulut, yang kemudian dapat menyebar ke kulit atau membran mukosa lainnya. Penyakit ini biasanya bermanifestasi antara dekade keempat dan keenam kehidupan, dengan predileksi antara laki-laki dan perempuan lebih kurang sama. PV secara klasik dipandang sebagai penyakit kulit, tetapi hampir selalu mengenai mukosa mulut. Mukosa mulut merupakan tempat pertama yang terlibat dalam mayoritas kasus, dan PV dapat hanya terbatas pada permukaan mukosa, atau meluas melibatkan kulit. Sebagian kecil akan hadir dengan erosi kulit, tetapi erosi oral terjadi pada hampir semua kasus. Pada pasien ini, manifestasi awalnya juga muncul pada rongga mulut, 7 bulan kemudian mulai muncul lesi di kulit.

Etiologi dan patogenesis yang pasti dari PV belum diketahui dengan jelas, namun berhubungan dengan interaksi antara faktor genetik dengan faktor lingkungan. Terdapat latarbelakang faktor genetik yang kuat yang berkaitan dengan alel HLA klas II. Alel ini berperan penting dalam pengenalan limfosit-T terhadap peptida Dsg3. Respon sel-T yang autoreaktif terhadap Dsg3 mempunyai peranan yang penting dalam patogenesis $\mathrm{PV}$, karena produksi antibodi umumnya membutuhkan bantuan sel-T. Individu dengan alel HLA klas II yang berbeda, menunjukkan sel-T mengenal epitop Dsg3 (umumnya CD45RO) yang membantu limfosit-B autoreaktif untuk menghasilkan autoantibodi. Sedangkan beberapa faktor eksogen yang telah diidentifikasi sebagai pencetus terjadinya PV meliputi: (1) makanan; terutama bawang putih, (2) obat-obatan terutama yang mengandung thiol seperti penicillamin dan captopril; dan obat yang mengandung fenol seperti rifampisin dan diklofenak, (3) virus; terutama virus herpes, dan (4) faktor lain seperti radiasi ultraviolet, sinar-X, terpapar 
pestisida yang berlebihan, stres emosional, vaksinasi, level estrogen yang tinggi pada kehamilan, dan terkait dengan penyakit autoimun lainnya seperti rheumatoid arthritis, myasthenia gravis, lupus erythematosus, atau anemia pernisiosa.

Infeksi virus, seperti herpes simplex virus (HSV), Epstein-Barr virus (EBV), cytomegalovirus (CMV) dan herpes virus 8 (HHV 8), berperan penting dalam memulai dan mencetuskan PV, serta mempertahankan dan memperburuk kondisi penyakit. Krain (1974) adalah orang yang pertamakali melaporkan kemungkinan peranan virus, terutama HSV dalam patogenesis PV. Dalam studi epidemiologinya terhadap 59 pasien $\mathrm{PV}$, dia menegaskan kenyataan bahwa 2 pasien mengalami PV setelah menunjukan infeksi herpes yang berat. Takahashi dkk. (1998) telah melaporkan adanya onset PV yang terjadi bersamaan dengan atau menyusul infeksi virus herpes. Pada pasien ini, onset PV terjadi setelah terjadinya infeksi virus herpes. Hal ini dapat dilihat dari pemeriksaan serologi yang menunjukan titer anti-HSV-1 IgG yang tinggi pada awal kemunculan lesi, dan titer antibodi menurun bersamaan dengan terjadinya remisi dari PV; dan kondisi penyakit kembali memburuk dengan kembali tingginya titer anti-HSV. Tufano dkk. (1999) telah meneliti kehadiran infeksi yang disebabkan oleh virus pada 20 pasien PV dengan menggunakan metoda PCR dari sampel biopsi dan pemeriksaan serologi darah tepi. Hasilnya ditemukan 19 pasien mempunyai serologi positif untuk CMV dan HSV, sedangkan dengan metoda PCR, ditemukan 10 pasien positif untuk HSV dan tidak satupun yang positif untuk CMV. Sejumlah kasus HSV sebagai pencetus atau memperburuk kondisi PV telah dikemukakan dalam sejumlah literatur, dan diamati bahwa pada kasus yang demikian, remisi menyeluruh dari lesi hanya terjadi setelah pemberian antivirus, dalam mayoritas kasus antivirus yang digunakan adalah asiklovir.

Pada kasus ini, walaupun sejak awal sudah terlihat adanya kenaikan titer antibodi
HSV-1, namun obat antivirus belum diberikan, dengan pertimbangan pasien tidak menunjukkan adanya tanda-tanda infeksi virus; seperti adanya demam sebelum kemunculan lesi. Disamping itu berdasarkan riwayat pengobatan sebelumnya, dimana pasien telah pernah mendapatkan asiklovir pada awal kemunculan lesi, namun tidak memberikan hasil. Dugaan mulai mengarah bahwa PV yang terjadi dipicu oleh infeksi virus, ketika terjadinya remisi penyakit bersamaan dengan turunnya titer anti HSV; dan penyakit kembali mengalami eksaserbasi seiring dengan kenaikan titer anti HSV. Remisi yang cepat dan menyeluruh terjadi setelah pasien diberikan asiklovir dosis tinggi.

Ada beberapa cara untuk menerangkan patogenesis hubungan antara agen infeksius dan pemfigus. Agen infeksi dapat merangsang respon imun pada individu yang rentan secara genetik, menyebabkan terjadinya peningkatan produksi dari interferon (IFN) dan interleukin (IL). Level yang tinggi dari IFN- $\gamma$ menyebabkan ekspresi dari HLA tipe 2 pada membran keratinosit, membuat tempat struktural dari antigen PV (penyebaran epitop) aktif secara imunologik. Infeksi virus yang kronis dapat juga menghasilkan produksi yang berlebihan dari IL-4 dan IL-10, yang menyebabkan pergeseran dari respon TH1 terhadap $\mathrm{TH} 2$, menyebabkan terjadinya peningkatan produksi antibodi; atau dapat juga secara langsung menginfeksi limfosit $\mathrm{T}$ dan $\mathrm{B}$, yang berkontribusi pada produksi limfosit B yang autoreaktif dan antibodi autoimun.

PV ditandai dengan terjadinya deposisi autoantibodi IgG terhadap glikoprotein desmosom, yang menyebabkan kerusakan desmosom oleh autoantibodi yang menyerang molekul-molekul adhesi sel epitel. Antigen utama pada PV adalah desmoglein 3 (Dsg3), namun 50\% pasien PV juga mempunyai autoantibodi terhadap Dsg1. Karena epitelium oral sebagian besar mengekspresikan Dsg3 (kulit mengekspresikan Dsg1 dan Dsg3), maka kerusakan Dsg3 mengakibatkan lesi oral 
pada tahap awal, sedangkan integritas kulit dipelihara oleh Dsg1. Namun jika kerusakan terhadap Dsg1 muncul, lesi kulit muncul dan penyakit cenderung menjadi lebih parah. Aktivitas penyakit umumnya berkaitan dengan level serum autoantibodi. Reaksi imun terhadap glikoprotein ini menyebabkan hilangnya kontak antar sel pada lapisan epitel (akantolisis), yang mengakibatkan pembentukan bulla intraepitel. Penekanan pada area kulit yang berdekatan dengan blister, akan membentuk blister baru, yang disebut sebagai Nikolsky's sign; suatu bantuan diagnostik yang penting untuk sejumlah penyakit bullosa.

Lesi oral biasanya dimulai sebagai vesikel atau bulla yang mudah ruptur, menghasilkan ulser dan erosi yang sakit, yang cenderung meluas karena epitelium yang terpisah pada perifer. Manifestasi lebih lanjut biasanya terdiri dari deskuamatif atau erosif gingivitis yang parah. Bibir dapat tertutup krusta hemoragik yang tebal. Pada tingkat lanjut, lesi dapat menyerupai eritema multiforme. Lesi PV dapat mengenai setiap bagian dari rongga mulut, namun tempat yang paling sering adalah pada daerah yang terkena trauma gesekan seperti mukosa bukal, lidah, palatum, bibir bawah dan gingiva. Lesi juga dapat mengenai membran mukosa lainnya, meliputi konjungtiva, mukosa hidung, faring, laring, esofagus, dan mukosa genital.

$$
\text { Diagnosis PV ditegakkan }
$$

berdasarkan riwayat penyakit dan gambaran klinis, serta dikonfirmasi dengan pemeriksaan histologik dan imunologik. Gambaran histologis klasik pada PV adalah akantolisis suprabasal, edema interseluler, dan kehadiran sel Tzank. Hal ini sesuai dengan hasil pemeriksaan histologis pada pasien ini, yang menunjukkan sel-sel epitel terpisah (akantolitik), ditemukan sel Tzank, dan lapisan basal yang tetap melekat ke membran basal. Direct immunofluorescence (DIF), digunakan untuk mendeteksi kehadiran autoantibodi, biasanya IgG dan komplemen yang terikat pada permukaan keratinosit. Nikolsky's sign pada pasien dengan ulserasi oral dapat dilakukan dengan pemberian tekanan mekanis yang ringan (tiupan angin, atau penekanan dengan tangkai kaca mulut) pada jaringan yang terkena.

Kortikosteroid sistemik masih merupakan terapi utama untuk pasien dengan lesi oral, terutama ditujukan untuk mencegah perkembangan penyakit agar tidak melibatkan kulit atau lesi pada epitel lain seperti osefagus. Pada pasien ini, walaupun sudah diberikan terapi kortikosteroid sistemik, lesi kulit masih muncul 7 bulan kemudian, namun tidak parah, hanya beberapa lesi di dada, punggung, tangan dan kaki. Rata-rata penghentian blister membutuhkan waktu 2-3 minggu, dan penyembuhan total dapat membutuhkan waktu 6-8 minggu. Aturan dosis optimum kortikosteroid sistemik tidak diketahui dengan pasti, dan didasarkan pada data empiris dan pengalaman praktis. Dosis yang dianjurkan, disesuaikan dengan tingkat keparahan penyakit. Pada kasus yang ringan, dirawat dengan dosis prednisolon awal 40-60 mg per hari, dan pada kasus yang lebih parah 60-100 mg per hari. Jika tidak ada respon dalam 5-7 hari, dosis dapat ditingkatkan 50$100 \%$. Pertamakali remisi terjadi, dosis diturunkan secara bertahap (tapering off). Terapi ajuvan direkomendasikan untuk mengurangi dosis steroid dan komplikasi serius yang dapat terjadi akibat penggunaan steroid; dan yang paling umum digunakan adalah obat-obatan imunosupresif seperti cyclophosphamide, cyclosporine dan azathioprine. Kebanyakan penelitian dari PV kulit menunjukkan penurunan mortalitas bila terapi ajuvan diberikan bersamaan dengan prednison. Namun suatu penelitian yang dilakukan selama 5 tahun pada kasus PV oral, menunjukkan tidak adanya keuntungan yang diperoleh dengan penambahan obat imunosupresan; dan sebaliknya menunjukkan tingkat komplikasi yang lebih tinggi pada kelompok yang menggunakan imunosupresan.

Untuk kasus PV yang terbatas hanya dalam rongga mulut, kebutuhan steroid 
sistemik dapat diturunkan dengan mengkombinasikannya dengan pemakaian steroid topikal dalam bentuk obat kumur atau salep. Perawatan deskuamatif gingivitis terdiri dari perbaikan higiene oral, meminimalkan iritasi, dan imunosupresif lokal. Diet lunak dan sikat gigi yang lembut dapat membantu meminimalkan trauma. Obat kumur antiseptik dapat digunakan untuk meningkatkan higiene oral. Lesi PV yang sukar disembuhkan (refractory) dengan terapi kortikosteroid, sebaiknya dilakukan investigasi virus, untuk mengetahui ada tidaknya keterlibatan virus. Penambahan antivirus, telah terbukti berhasil dalam perawatan PV yang terkait infeksi virus.

Pada pasien ini terapi yang diberikan berupa kombinasi kortikosteroid sistemik maupun topikal; untuk mengurangi dosis steroid sistemik, perbaikan higiene oral dengan melakukan skeling dan ekstraksi radiks serta kumur larutan antiseptik khlorheksidin glukonat; yang bertujuan untuk mencegah terjadinya infeksi sekunder dan mempercepat penyembuhan. Kondisi mulut terlihat mengalami perbaikan $\pm 2,5$ bulan sejak terapi steroid dimulai, namun ulserasi di mukosa bukal dan deskuamatif gingivitis masih tetap ada. Penambahan terapi dengan asiklovir, diberikan setelah terjadi eksaserbasi lesi, dan lesi mengalami remisi menyeluruh dalam waktu yang lebih cepat.

\section{KESIMPULAN}

Lesi PV yang sukar disembuhkan dengan terapi konvensional dengan kortikosteroid, sebaiknya dilakukan investigasi adanya keterlibatan virus. Apabila infeksi virus teridentifikasi, kombinasi agen antivirus dan terapi imunosupresif mempunyai peranan penting. Pemberian asiklovir telah terbukti berhasil dan memberikan remisi yang menyeluruh dari lesi.

\section{DAFTAR PUSTAKA}

Brandao ML, Fernadez NC, Batista DP, Santos N. Refractory pemphigus vulgaris associated with herpes infection: case report and review. Rev Inst Med Trop. 2011;53(2):113-17.

Da Silva K, Mandel Louis. Early manifestation of pemphigus vulgaris: a case report. NYSDJ. 2007:42-4.

Regezi JA, Sciubba JJ \& Jordan R. Oral Pathology: Clinical Pathologic Correlations, $4^{\text {th }}$ ed. Philadelphia: WB Saunders Company; 2003.p.11-5.

Ohta $\mathrm{M}$ et al. Pemphigus vulgaris confined to the gingiva: a case report. Int $\mathrm{J}$ of Dent. 2011:1-4.

Dagistan S, Goregen M, Miloglu O, Cakur B. Oral pemphigus vulagaris: a case report with review of the literature. J of Oral Science. 2008;50(3):359-62.

Black M, Minogna MD, Scully C. Pemphigus vulgaris. Oral Dis. 2005;11:119-30.

Scully C. Pemphigus Vulgaris: update on ethiopathgenesis, oral manifestations, and management. Crit Rev Oral Biol Med. 2002;13(5):397-408.

Woo SB \& Greenberg MS. Ulcerative, Vesicular, and Bullous Lesions. In Greenberg MS, Glick M, Ship JA. eds. Burket's Oral Medicine. $11^{\text {th }}$ ed. Hamilton: BC Decker Inc; 2008.p.625.

Rimal J, Sumanth KN, Ongole R, George T, Chatterjee S. A rare presentation of oral pemphigus vulgaris as multiple pustules: case note. Kathm Univ Med J. 2007;5(4):541-45. 
Ata-Ali F, Ata-Ali J. Pemphigus vulgaris and mucous membrane pemphigoid: update on etiopathogenesis, oral manifestation and management. $\mathbf{J}$ Clin Exp Dent. 2001;3(3):246-50.

Harman KE, Albert S, Black M. Guidelines for the management of pemphigus vulgaris. Brit $\mathrm{J}$ of Derm. 2003;149:926-37.

Reddy B, Choudary P, Hasan S. Pemphigus vulgaris a chronic blistering mucocutaneous disorder: an overview. Oral Med \& Radiol. 2012 January:45-7.

Samim $\mathrm{T}$ et al. Pemphigus vulgaris in oral cavity: clinical analysis of 71 cases. Med Oral Patol Oral Cir Bucal. 2008;13(10):622-6. 